\title{
The Impact of Effective Human Resource Management Practices on Job Satisfaction: The Case of National Bank of Greece
}

\author{
Efstathios Dimitriadis ${ }^{1}$ Anna Sarafidou ${ }^{2}$ Despoina Kaltsidou ${ }^{3}$
}

\begin{abstract}
:
An organization's success in today's competitive business environment is mainly based on human capital and banking institutions and there is no exception to this. Satisfied and loyal employees are the most important assets of an organization, and primarily responsible for productivity and profitability. This study examines the level of employee satisfaction in the National Bank of Greece and attempts to identify the contributing factors. The survey covered 366 employees in Greek branches of the National Bank of Greece, and was conducted with the use of a questionnaire. The analysis of the results indicated moderate levels of job satisfaction in the majority of employees while the main factors contributing to job satisfaction were collegial relationships and relationships with superiors. By contrast, the promotion policy and potential empowerment and participation, may probably need improvement and corrective measures as they not only don't constitute a source of satisfaction for the employees of the National Bank of Greece, but fluctuate within the limits of neutrality and discontent.
\end{abstract}

Key Words: Human Resource Management, Job Satisfaction, Banking Sector, National Bank of Greece.

JEL Classification: $M 1$, O15

\footnotetext{
${ }^{1}$ Corresponding Author: Assistant Professor of Applied Statistics, Eastern Macedonia and Thrace Institute of Technology, Department of Business Administration, Kavala, Greece, Agios Loukas, 65 404. Tel. and Fax:0030 2510462304, Email: edimit@teikav.edu.gr.

${ }_{3}^{2}$ A Bank Executive in the National Bank of Greece, Drama, Greece, Sarafidou@gmail.com

${ }^{3}$ Ph.D Cadidate. Democritus University of Thrace, Department of Social Administration, KomotiniGreece, deskal85@gmail.com
} 


\section{Introduction}

In an economic environment that is rapidly changing in political, economic, cultural and technological level, the human is faced with a plethora of opportunities and challenges while is one of the most crucial factors in achieving business objectives. Every business has to make a long term investment in human resources, focusing on proper recruitment, training and assessment.

Bernardin and Russell (2003), argue that three are the main factors that play a crucial role in achieving sustainable competitive advantage of a company relative to its competitors: (1) reduce operating costs, (2) product differentiation and (3) human resources and its level of expertise.

The human capital which is knowledge, education, abilities, skills and the expertise of the workforce of a business (Crowford, 1991), is emerging as the most important element that helps them not only to survive but to thrive and prosper. Acquiring capital and technology can be realized in various ways. However, in today's business environment, the dominant competitive advantage is its highly skilled and committed workforce (Frauenheim, 2008).

Job satisfaction is considered to be very important not only for employees but also for the success of the organization (Lim, 2008). The lack of job satisfaction leads to loyalty failure, insufficiency in commitment and faith towards to the company and therefore it results in the search of new jobs (Reed et al., 1994). Work satisfaction is the difference between the expectations and desires of the people associated with the work, and what it is actually offered (Saleem et al., 2013). Job satisfaction can also be defined as the degree to which work is pleasant for the employees (Spector, 1997).

In today's globalized market, the financial sector is characterized by a dynamic of constant changes and upheaval. In Greece during the last decades the banking sector has experienced remarkable growth and prosperity, with the exception of the last five years, during which was rocked by the serious consequences of the financial crisis. Their role has been significantly upgraded, with the creation of new conditions of globalized economy and the rapid development of technology.

In a country like Greece, in the period of global recession and financial crisis, the growth and sustainability of the banking institutions depends on the ability to adapt to economic developments and changes. Having the expertise and focusing on new customer-driven systems, in order to maintain long-term relationships with their customers, banks are in constant struggle to cope with the needs and requirements of international and domestic financial markets. Fixed reference point but also a key sustainable competitive advantage for each bank is its human capital (Protopapas, 
1997). The banks' strategies of acquiring, maintaining and using the appropriate human resources, can contribute to the increase of production and competitiveness. Human resources, in contrast to the material resources, constitute the link between the customers and changing market conditions. The improvement of quality and the personalization of banking services, make human capital the main factor of high performance. The National Bank was founded in 1841 and was the first bank in the Modern Greek state, with a decisive contribution to the economic life of the country in the 170 years of history. Today, the National bank leads one of the largest and strongest financial groups in Greece, with a strong presence in Southeastern Europe and the Eastern Mediterranean.

With 531 branches and 1.400 ATMs, it has the widest service network covering the entire geographical area of Greece, while simultaneously it develops alternative distribution channels for its products, such as Mobile and Internet Banking. Today, the Group's network overseas includes 1.235 units, while the Group employs a total of 35.244 employees, serving a market of 125 million inhabitants (31.03.2014). The National Bank employs 9.782 employees in Greece (01.01.2014)

The National Bank of Greece recognizes the importance of human resources, as it is the main factor for the development and business success. Investing in the continuous upgrading of its personnel shows particular attention to the selection, training, appraisal and development. In 2012 the National bank offered 228.831 hours of training with an average of 15 hours per employee and an expenditure of about 3 million Euros. Key priorities are to ensure a safe working environment, equal opportunities and rights for all, to provide educational opportunities and develop new skills of its employees and the implementation of a merit-based performance evaluation system. The principles and values of the Code of Conduct and Ethics, determine the daily operations and activities of the Bank's staff, which are governed by the following principles: (1) Legality, (2) Priority to the customers, (3) Quality of the staff (4) Contribution to the community and (5) Respect to the environment.

The bank's objective is to attract and retain competent human resources who will embrace the values and principles of the National Bank, will contribute to fulfilling the objectives of the organization and seeks to continue its dynamic course.

The main objective of this study is to measure the degree of job satisfaction of employees in the National Bank and moreover to investigate the factors of human resource management that affect job satisfaction. 


\section{Literature Review and Hypotheses Formulation}

Abdullah and Djebavni (2011), in an effort to discover and categorize the factors affecting job satisfaction, highlighted the level of remuneration, including salary and additional performance incentives as the most decisive factor in employment satisfaction, but also other factors such as promotion prospects, recognition of the work, and work faith and loyalty (Calisir et al., 2010).

Ali and Ahmed (2009), conclude that changes in reward and recognition programs, causing a corresponding change in work motivation and satisfaction, which means that greater emphasis on reward and recognition from their superiors, can mobilize workers and therefore lead to higher levels of job performance. Moreover, positive and statistically significant correlation was found between job satisfaction and administrative practices, such as teamwork, self-reliance and leadership-supervision (Hunjra et al., 2010).

Spector (1997), considered the most popular means of job satisfaction and summarized in the following aspects of job satisfaction: the recognition of his superiors, assessment, communication, relationships with colleagues, extra benefits, working conditions, the nature of work and the company itself, the company policies and procedures, fees, personal development, promotional opportunities, the sense of security and supervision. According to Davis and Newstrom (1999), the job satisfaction is an experience in various aspects, of which the most important is related to the circumstances and the nature of work itself. The low degree of autonomy, job insecurity, low wages and the lack of promotion opportunities negatively affects job satisfaction (Guest, 2004; Silla et al., 2005).

Abdullah and Djebavni (2011), examining the relationship between job satisfaction, working environment and demographic factors, found that the salary, promotion and supervision are the best predictors of job satisfaction, compared with demographic information, such as gender, age and education level, and other factors related to professional experience, such as the level of the job, shift work and years of service. They also resulted in the significant impact of rewards, incentives, corporate strategy and policy and the nature of work in job performance.

Lai (2011), argues that an effective rewards system contributes to business growth and expansion and presents a positive relationship between-employee satisfaction and salaries which are based on skills and performance. The study concludes that the intrinsic motivation factors, including the identification, nature of work, opportunities for professional development and responsibility, have a significant relation with job satisfaction. According to Opkara (2002), factors such as rewards, nature of work, supervision, relationships with colleagues and development opportunities has been found to contribute to job satisfaction. 
The achievements of individual and organizational goals are independent processes associated with providing work incentives for workers. The organization must motivate employees to align their personal goals with business strategy. This means that the objectives of the organization are in direct dependence on the personal aspirations of workers. A significant number of studies have shown that working conditions are positively related to job satisfaction and organizational commitment (Pati and Reilly 1977; Mahajan et al. 1984; Putti and Kheun, 1986; Ruth 1992; Gratto 2001; Clercq and Rius, 2007).

The attitude of employees towards the company-employer, has a large impact on how their work and their contribution to overall organizational performance and is directly linked to incentives (Stringer, 2002). A satisfied, sufficiently motivated and less stressed workforce is the result of an organization with consistency, structure, systematic work and work culture in harmony with the business strategy (Nguyen et al., 2003).

The job satisfaction arises from many different factors, such as satisfaction with pay, promotion opportunities, extra benefits, job security and attention that gives the employee to work (Iaffaldano and Muchinsky, 1985). Thus, they concluded that the alleged relationship between job satisfaction and job performance was a "management obsession" and "illusion". This study had a significant impact on researchers, business managers and human resources managers, who were led to believe that the relationship between job satisfaction and performance was negligible

Significant difference appears to exist in the levels of job satisfaction, based on income. Workers with the lowest income had significantly lower levels of job satisfaction compared with employees of other categories of income. To fair system of promotion and career development, labor autonomy, inspired leadership behavior, social relationships between colleagues and the nature of work itself is also among the most important factors of job satisfaction (Dawson, 1987).

Karatepe et al. (2006), argued that the enhancement of job satisfaction is the key to maintaining workers in long-term employment. There are six characteristics: the nature of work, supervision, the collegial relationships, rewards, promotion opportunities and overall job security, which appear to contribute to job satisfaction (Lehal, 2004). Using temporal data, Nguyen et al. (2003), studied the determinants of job satisfaction, determining rewards, the behavior of superiors, working hours, job autonomy and personal characteristics. Chow and Luk (1996), identified the good relationships with their superiors as a catalyst for job satisfaction.

Hanif and Kamal (2009), argue that the favorable development strategies and business practices, related to salary scales, hiring staff and working environment can lead to organizational employee engagement, satisfaction and increased loyalty 
employees of the business. Satisfied employees are more likely to be friendly and helpful and to attract customers, while dissatisfied employees can lead to customer dissatisfaction (Hanif and Kamal, 2009).

Elanian (2009), in a research in the United Arab Emirates, argued that workers prefer clear goals and objectives, well-defined responsibilities and autonomy to avoid job insecurity. Moreover, were highlighted significant differences on job satisfaction which are due to gender, qualifications, work experience, and job characteristics (Ahmed et al., 2010).

Butt et al. (2007), conclude that the salaries, promotion and training affect positively and significantly to job satisfaction. Akbar et al. (2011) confirmed that the empowerment, participation in decision making and the ability to take initiatives for workers leads to higher levels of job satisfaction. Calisir et al. (2010) found a very strong effect of job satisfaction on organizational commitment, whereas job stress and uncertainty of job responsibilities indirectly affect the willingness of workers to leave their jobs

(Hunjra, 2010), concluded that the majority of workers in his research, agrees that the type of personality must match with the nature and characteristics of their work, and want to have the opportunity to use their knowledge and skills while performing their job. He also argued that recruitment and selection of employees is an important predictor of job satisfaction, and that fair recruitment policy and selection lead to job satisfaction.

Nguyen et al. (2003), found that the higher the educational level of workers is, the lower the job satisfaction. Kennedy and White (1997), concluded that the training of employees within the organization play a key role in improving and developing the quality of service, while enhancing the skills of employees and ultimately increases customer and employee satisfaction and loyalty to the firm.

Mohanty (2009), presented specialized practices for employee retention in the organization. He said that practices such as open communication, rewards programs, professional development programs, extra rewards based on performance, leisure and gifts in certain circumstances can help the organization to maintain its workforce. He also added that open communication keeps employees informed on key issues relating to the corporate functioning and support their participation in decision making. Similarly, recreation facilities help the staff to remove work-related stress.

According to Thakur (2007), the best way to improve productivity is the unremitting effort to achieve the common goals of employees and the organization. Making employees stakeholders in fulfilling its corporate mission, in establishment of 
policies and procedures, to provide privileges, etc., improved internal communication, enhanced morale and job satisfaction

The effect of employee's level, age, gender and previous experience in the job satisfaction has been studied by Oshaghemi (2003), in UK universities. The study found that the level of an employee is an important predictor of job satisfaction, and that there is a strong positive correlation between them. Similarly, the length of previous experience was found to be significantly and negatively correlated with job satisfaction, while age and gender were found not to be significant.

There is a great debate in the literature on the role of gender in job satisfaction, but there is a wide variance in the findings of different studies. Some studies have shown that women workers are more satisfied with their jobs than male workers, while other studies provided the opposite (Weaver 1974; Shaprio and Stern, 1975; Forgionne and Peters, 1982; Clark, 1997; Ward and Sloane, 1998).

Cambell et al. (1976) argued that there is a difference between the expectations of men and women in terms of their jobs, which may be the cause of the difference in the level of job satisfaction between men and women. According to Lee and Ho (1989) and Wilkinson (1998), employee participation in decision-making and empowerment is positively correlated with job satisfaction.

According to all above mentioned, we can formulate the following hypotheses:

$\mathrm{H} 1$ : There is a positive relationship between employees' salaries and job satisfaction.

$\mathrm{H} 2$ : There is a positive relationship between the promotion and evolution opportunities and job satisfaction.

$\mathrm{H} 3$ : There is a positive relationship between organizational aspects and job satisfaction.

H4: There is a positive relationship between the relationships with supervisors and job satisfaction.

H5: There is a positive relationship between working conditions and employee job satisfaction.

H6: There is a positive relationship between the relationships with co- workers and job satisfaction.

H7: There is a positive relationship between empowerment and participation of employees and job satisfaction.

H8: There is a positive relationship between training and development of employees and job satisfaction. 


\section{Research Methodology}

\subsection{Population- Sample and Data Collection}

The 9.782 employees of the National Bank of Greece constituted the sample of the research. A structured questionnaire was used as research instrument, which was distributed by e-mails in 1000 employees, randomly selected. The distribution of the questionnaires took place in September of 2013 and the final sample size, which is constituted by 366 questionnaires, ensures a sufficient degree of representativeness in the sample and a high degree of reliability in the results. 59,2\% were women while $40,8 \%$ were men. It is obvious that more women answered to our survey than the men. The actual proportion of employees in the bank, is 53,5\% male and $46,5 \%$ female. Regarding the age of the respondents the highest percentage $(42,2 \%)$ is between 26 and 35 years old and 39,2\% between 36 and 50 years old. Regarding the marital status of the respondents the vast majority are married $(61,9 \%)$ and $33,4 \%$ are unmarried.

The educational level of the employees of the bank is quite high as $36 \%$ are university graduates and $16,8 \%$ holds a master or a doctoral degree. From the above results we can conclude that banks prefer to hire workers with high educational level in order to be able to cope with the increasing demands of the banking industry. In the sample $52,5 \%$ are university graduates, $30,1 \%$ hold a master or doctoral degree, while only $17,2 \%$ are reported to have a high school degree. Therefore, we could conclude that mainly workers with higher education levels have responded to our survey.

The majority of workers who responded to our survey have less than 10 years experience in the National Bank (43,7\%). Follow, employees who have between 1014 years experience $(16,4 \%)$, while employees who are closer to retirement, with over 30 years of experience, are $11,7 \%$.

As far as the job position of respondents is concerned $51,1 \%$ are office workers, $27,5 \%$ are Heads of departments, while 21,4\% are senior officials (Director, Deputy Director, Executive).

\subsection{Questionnaire's Description}

The construction of the questionnaire was based on an extensive literature review and attempts investigate the main factors that affect job satisfaction.

The questionnaire consists of three parts. The first part of the questionnaire refers to the demographic and personal data of the respondents (gender, age, marital status, education level and years of experience). 
The second part investigates the job satisfaction of employees in the National Bank of Greece and consists of 32 questions adapted to similar studies worldwide (Hassan et al. 2011; Nikolaidou, 2010; Shrivastava and Purang, 2009; Sowmya and Panchanatham, 2011; Papageorgiou and Papatzika 2011; Grammatikou, 2010; Turkyilmaz et al., 2011; Vallejo et al., 2001). A five-point Likert scale was used (1 = strongly disagree, $2=$ disagree, $3=$ neither disagree nor agree, $4=$ agree and $5=$ strongly agree) for all the questions of the second part of the questionnaire which are in the form of statements.

The third part examines the overall job satisfaction and was measured using one question with the following classification: $1=$ Not at all, 2=Little, 3=Somewhat, $4=$ To a Great Extent and 5= To a Very Great Extent (Nicolaidou, 2010).

\subsection{Validation of Research Instrument}

In order to validate the questionnaire used in the research, it was tested for content validity, construct validity and reliability.

\subsubsection{Content Validity}

Zikmund (1997), argued that the main form of validity is the content validity, which examine if the specific variables chosen actually measure the under consideration subject. The questionnaire used in the research is constituted by items selected from other similar researches. Furthermore, a pilot test in a panel of academics and professionals was performed.

\subsubsection{Construct Validity}

According to Cao and Dowlatshahi (2005), the three components of construct validity are: unidimentionality, convergent validity and discriminant validity. To establish the unidimentionality of factors, an exploratory factor analysis using principal component analysis with varimax rotation was performed and eight factors emerged (Table 1). Bartlett's test of sphericity was significant (Sig. of Chi-Square $=0,000$ ) and moreover, the Measure of Sampling Adequacy (M.S.A) of KaiserMayer-Olkin (K.M.O), which is the most popular diagnostic measure Sharma (1996), was 0,908. According to Sharma (1996) K.M.O should be greater than 0,7. As factors all these with Eigenvalue greater than 1 were determined. Finally, as far as the test of significance of items is concerned the factor loadings were checked. In a sample of more than 250 individuals, a loading of 0.35 is considered as significant (Hair et al., 1995). As shown in the table 1, all the loadings ranging from 0,508 to 0,849 . 
Table 1: Factor Analysis

\begin{tabular}{|c|c|c|c|}
\hline Statements & Factors & Loadings & $\begin{array}{c}\text { Variance } \\
(\%)\end{array}$ \\
\hline $\begin{array}{l}\text { 1. The level of my salary is sufficient } \\
\text { 2. My salary is enough for providing } \\
\text { necessary things in my life } \\
\text { 3. Comparing, the salary for similar jobs in } \\
\text { other banks, I feel my pay is better. }\end{array}$ & $\begin{array}{c}\text { A1. } \\
\text { Salaries }\end{array}$ & $\begin{array}{l}0,840 \\
0,755 \\
0,776\end{array}$ & 7,271 \\
\hline $\begin{array}{l}\text { 1. Promotions are made on merit in this } \\
\text { Bank } \\
\text { 2. I have been getting promotion according } \\
\text { to qualification and experience } \\
\text { 3. The political beliefs of employees do not } \\
\text { affect their official development in the } \\
\text { Bank. } \\
\text { 4. Favoritism does not have any role in the } \\
\text { National bank }\end{array}$ & $\begin{array}{l}\text { A2. } \\
\text { Opportunities } \\
\text { for Promotion } \\
\text { and Evolution }\end{array}$ & $\begin{array}{l}0,793 \\
0,780 \\
0,750 \\
0,678\end{array}$ & 11,870 \\
\hline $\begin{array}{l}\text { 1. The Bank supports my participation in } \\
\text { decision making. } \\
\text { 2. Responsibilities and tasks and } \\
\text { responsibilities are shared equitably. } \\
\text { 3. The degree of freedom for initiative in } \\
\text { the context of my work is satisfactory. }\end{array}$ & $\begin{array}{c}\text { A3. } \\
\text { Empowerment } \\
\& \\
\text { Participation }\end{array}$ & $\begin{array}{l}0,508 \\
0,569 \\
0,506\end{array}$ & 5,502 \\
\hline $\begin{array}{l}\text { 1. I feel proud for working in the National } \\
\text { bank } \\
\text { 2. I think tha the National bank treats its } \\
\text { employees better than any other bank } \\
\text { 3. I have full confidence in the management } \\
\text { of this bank. } \\
\text { 4. I feel that my job is reasonably secure as } \\
\text { long as my working performance is good. } \\
\text { 5. My bank builds on my qualifications, } \\
\text { skills, abilities and experience. } \\
\text { 6. The working conditions in the National } \\
\text { Bank are satisfactory. } \\
\text { 7. The subject of my work is interesting. }\end{array}$ & $\begin{array}{c}\text { A4. } \\
\text { Organizational } \\
\text { aspects }\end{array}$ & $\begin{array}{l}0,748 \\
0,607 \\
0,610 \\
0,565 \\
0,528 \\
0,593 \\
0,546\end{array}$ & 9,281 \\
\hline $\begin{array}{l}\text { 1. I am satisfied with the general } \\
\text { supervision in my department. } \\
\text { 2.My supervisor keeps me informed about } \\
\text { all policies/happenings in the bank } \\
\text { 3. My supervisors recognize and reward the } \\
\text { results of mywork. } \\
\text { 4. I feel free to contact my Manager / } \\
\text { Supervisor when needed. } \\
\text { 5. My supervisor is an effective leader }\end{array}$ & $\begin{array}{c}\text { A5. } \\
\text { Relations with } \\
\text { supervisors }\end{array}$ & $\begin{array}{l}0,757 \\
0,756\end{array}$ & 13,221 \\
\hline
\end{tabular}


The Impact of Effective Human Resourse Management Practices on Job Sattisfaction: The Case o National Bank of Greece

\begin{tabular}{|c|c|c|c|}
\hline & & 0,794 & \\
\hline $\begin{array}{l}\text { 1. The total number of my vacation days is } \\
\text { sufficient } \\
\text { 2. The daily hours of work is not excessive } \\
\text { 3. The daily volume of my work is normal. }\end{array}$ & $\begin{array}{l}\text { A6. } \\
\text { Working } \\
\text { Conditions }\end{array}$ & $\begin{array}{l}0,595 \\
0,743 \\
0,821\end{array}$ & 6,601 \\
\hline $\begin{array}{l}\text { 1. My job provides opportunities to } \\
\text { develop new skills and competencies. } \\
\text { 2. My work offers opportunities for } \\
\text { professional training (seminars, workshops, } \\
\text { other programs). } \\
\text { 3. The education policy applied by the Bank } \\
\text { helps me to be more effective in my work }\end{array}$ & $\begin{array}{c}\text { A7. } \\
\text { Training and } \\
\text { Development }\end{array}$ & $\begin{array}{l}0,710 \\
0,849 \\
0,802\end{array}$ & 8,842 \\
\hline $\begin{array}{l}\text { 1. There is high team spirit in the work } \\
\text { group } \\
\text { 2. I have satisfactory interpersonal } \\
\text { relationships with my co- workers } \\
\text { 3. I often ask the opinion of my co-workers } \\
\text { who work in my unit } \\
\text { 4. Communication between my co- workers } \\
\text { and me is free and open }\end{array}$ & $\begin{array}{l}\text { A8. } \\
\text { Relations with } \\
\text { co-workers }\end{array}$ & $\begin{array}{l}0,734 \\
0,798 \\
0,749 \\
0,765\end{array}$ & 8,976 \\
\hline & & $\begin{array}{c}\text { Total } \\
\text { Variance } \\
\end{array}$ & $71,563 \%$ \\
\hline
\end{tabular}

Discriminant validity copes with the concept that differing constructs should be dissimilar (Burns and Bush, 1995). An indicator of discriminant validity can be found if the correlation coefficients between the pairs of the variables are less than the Cronbach's alpha (Churchill, 1979). The findings from the test were very satisfactory (Table 2).

Table2. Discriminant Validity and Reliability Analysis

\begin{tabular}{|c|c|c|c|c|c|c|c|c|}
\hline Factors & A1 & A2 & A3 & A4 & A5 & A6 & A7 & A8 \\
\hline A1 & $\mathbf{0 , 7 6 4}^{\mathbf{a}}$ & & & & & & & \\
\hline A2 & 0,246 & $\mathbf{0 , 8 4 9}^{\mathbf{a}}$ & & & & & & \\
\hline A3 & 0,250 & 0,628 & $\mathbf{0 , 7 7 8}^{\mathbf{a}}$ & & & & & \\
\hline A4 & $-0,063$ & 0,015 & 0,041 & $\mathbf{0 , 8 5 3}^{\mathbf{a}}$ & & & & \\
\hline A5 & 0,265 & 0,518 & 0,572 & 0,131 & $\mathbf{0 , 9 1 6}^{\mathbf{a}}$ & & & \\
\hline A6 & 0,270 & 0,252 & 0,334 & 0,014 & 0,268 & $\mathbf{0 , 6 8 3}^{\mathbf{a}}$ & & \\
\hline A7 & 0,254 & 0,425 & 0,490 & $-0,013$ & 0,374 & 0,392 & $\mathbf{0 , 8 3 5}^{\mathbf{a}}$ & \\
\hline A8 & 0,149 & 0,357 & 0,392 & 0,035 & 0,578 & 0,339 & 0,382 & $\mathbf{0 , 8 5 6}^{\mathbf{a}}$ \\
\hline
\end{tabular}

${ }^{\mathrm{a}}$ Cronbach's alpha

Convergent validity correlates with the degree to which multiple methods of measuring a variable provide the same results (Spector, 1992; Churchill, 1979). 
Convergent validity is believed to be acceptable when all item loadings are more than 0,5 (Wixom and Watson, 2001) and the items for all construct load onto one factor with an eigenvalue greater than 1 . All items have load greater than 0,5 and the eigenvalue for all factors were greater than 1 (Table 1).

\subsubsection{Reliability}

Finally, a reliability test, which measures the internal consistency, was performed using Cronbach's alpha coefficient. Nunally (1978), suggests that Cronbach's alpha should be more than 0,7 so as to be characterized a construct reliable. In this study all the indices were greater than 0,7 (Table 2).

\section{Data Analysis-Results}

\subsection{Basic Statistics}

The first step of data analysis refers to the basic statistics of the human recourse practices which affects to the overall job satisfaction.

Table 3: Basic Measures

\begin{tabular}{|l|c|c|c|}
\hline \multicolumn{1}{|c|}{ Factors } & Mean & $\begin{array}{c}\text { Standard } \\
\text { Deviation }\end{array}$ & $\begin{array}{c}\text { Coefficient of } \\
\text { Variation (\%) }\end{array}$ \\
\hline Salaries & 3,04 & 0,882 & 29,06 \\
\hline Opportunities for Promotion \& Evolution & 2,64 & 0,881 & 33,33 \\
\hline Empowerment and Participation & 2,83 & 0,818 & 28,89 \\
\hline Organizational Aspects & 3,41 & 0,787 & 23,07 \\
\hline Relations with supervisors & 3,59 & 0,932 & 25,94 \\
\hline Working Conditions & 3,44 & 0,862 & 25,06 \\
\hline Training and Development & 3,37 & 0,874 & 25,94 \\
\hline Relations with co- workers & 3,79 & 0,776 & 20,43 \\
\hline Job Satisfaction & 3,30 & 0,836 & 25,35 \\
\hline
\end{tabular}

The factor "Opportunities for Promotion and Evolution" with the lowest average value (2.64), shows that participants are not satisfied as to the fairness, impartiality and objectivity of the process of career development in branches of National Bank. Also they do not appear confident $(2,83)$ for the empowerment opportunities that the Bank offers with the ability to take initiatives and participation in decision-making.

On the other hand, the factor "Relations with Co-Workers" received the highest mean $(3,79)$, indicating a satisfactory level of cooperation, the existence of relationships and open communication between colleagues. Followed, in descending 
order factor "Relations with Supervisors" with mean 3,59, which indicates a slightly more limited degree of satisfaction than that measured in the "Relations with CoWorkers".

The factor "Salaries" appears almost to the mean of the scale of satisfaction. With an average of 3,04 the majority of the sample said neither dissatisfied nor satisfied with the received salary. This fact should be associated with the recent reductions of salaries, not only of the employees of the National Bank but in general in all the Greek banks.

Very little satisfaction, verging neutrality observed factors "Organizational aspects" with a mean of 3,41, "Working Conditions" with a mean of 3,44 and "Training and Development" with a mean of 3,37

The average values of the majority of the factors characterized by excess or lack of satisfaction or dissatisfaction. They appear to be around value 3 , reflecting moderate levels of satisfaction or dissatisfaction from respondents. This fact is confirmed by the overall job satisfaction, which in an average value of 3,30, indicating a slightly greater satisfaction than average.

\subsection{ANOVA}

In order to define differentiations of the opinion of respondents, due to demographic characteristics, an Analysis of Variance was performed. The results indicate that:

Gender is a factor of differentiation only as far as the «Salaries» ( $f=9,214$ sig=0,003). Especially, men are less satisfied than women.

Age is a cause of differentiation of factors «Salaries» $(\mathrm{f}=3,433$-sig=0,009), «Training and Development» $(\mathrm{f}=2,938$-sig $=0,021)$, «Relations with co- workers» $(\mathrm{f}=2,882-$ sig=0,023). The older workers are less satisfied.

The family status affects the level of satisfaction of factors: «Opportunities for Promotion and Evolution» ( $\mathrm{f}=4,749$ sig=0,009), «Training and Development» $(\mathrm{f}=3,365$-sig=0,036) and «Overall Satisfaction»» $(\mathrm{f}=4,502$-sig=0,012). The unmarried were less satisfied than the married.

The level of education of employees differentiates the level of satisfaction of the factors: «Salaries» $(\mathrm{f}=6,770$-sig=0,000), «Opportunities for Promotion and Evolution» ( $\mathrm{f}=3,077$-sig $=0,028)$, «Working Conditions» $(\mathrm{f}=2,978$-sig=0,032) and «Relations with co- workers» $(\mathrm{f}=4,980$-sig=0,002). In all cases graduates of high school are more dissatisfied.

The factors «Salaries» $(\mathrm{f}=4,699$-sig $=0,000)$, «Training and Development» $(\mathrm{f}=3,376-$ $\operatorname{sig}=0,003)$ and «Relations with co- workers» $(\mathrm{f}=2,184$-sig $=0,044)$ depend on work experience. Employees with little experience are more satisfied. 
Finally, the job position in the National Bank differentiates the level of satisfaction of the factors «Salaries» $(\mathrm{f}=7,777$-sig $=0,000)$, «Empowerment and Participation» $(\mathrm{f}=5,539$-sig $=0,004)$ and «Training and Development» $(\mathrm{f}=5,217$-sig=0,006). The senior executives are less satisfied with their salaries compared to others. The staff is quite unsatisfied with opportunities for participation and empowerment and opportunities for training and development.

\subsection{Test of Hypotheses}

In order to test the hypotheses, a multiple regression analysis was performed. As dependent variable of the regression analysis, the overall job satisfaction was used, while the eight factors were the independent variables. From the analysis, results that the data are appropriate for regression analysis as the value of $F$ statistics $(18,139)$ is statistically significant $(\mathrm{sig}=0,000)$. The independent variables explain the $43,2 \%$ of the total variance while there is no evidence of autocorrelation as the DurbinWatson index has a value of $1,899 \approx 2$. Moreover all the V.I.F indices are less than 5 and thus the factors are not characterized by collinearity.

The standardized coefficients Beta and their significance constitute the effective control of research hypotheses which are formulated.

Thus, hypothesis $\mathrm{H} 1$, according to which there is a positive relationship between the salaries of employees and job satisfaction, fully verified as the value 0,270 of Beta coefficient is statistically significant (sig. $=0,000)$. It therefore concluded that the level of earnings has a positive effect on job satisfaction.

The same resulted for hypotheses $\mathrm{H} 2$ (There is a positive relationship between the promotion and evolution opportunities and job satisfaction) and H3 (There is a positive relationship between organizational aspects and job satisfaction) which are accepted in a $10 \%$ level of significance (sig. $=0,054$ and Beta $=0,143$ for $\mathrm{H} 2$ ) \& (sig. $=0,077$ and $\mathrm{Beta}=0,137$ for $\mathrm{H} 3$ ). This leads us to the conclusion that the fair promotion policy and career development, as well as operational factors relating to confidence in management, occupational safety, the use of qualifications and a good working environment, have a positive effect on job satisfaction.

Hypotheses H4 (There is a positive relationship between relationships with supervisors and job satisfaction) and 5 (There is a positive relationship between the working conditions of employees and job satisfaction) are rejected as the Beta values of the coefficients are statistically insignificant (sig. $=0.803$ for $\mathrm{H} 4 \&$ sig. $=0,193$ for H5). Therefore we conclude that the administrative behavior of supervisors, the relations with supervisors and the working conditions referred to time and the amount of work does not have a significant impact on job satisfaction of employees in the National Bank 
The hypothesis H6, according to which there is a positive relationship between the relationships with colleagues and job satisfaction is accepted at a significance level of $10 \%$ as Beta $=0,113$ and sig $=0,068$. Therefore, good cooperation, team spirit, good interpersonal relations and open communication with colleagues, positively affect job satisfaction.

Hypothesis H7 (There is a positive relationship between empowerment and participation of employees and job satisfaction) is rejected, since the Beta coefficient is statistically insignificant $(\mathrm{sig}=0,517)$, resulting that the opportunities for empowerment and participation in decision-making, do not affect significantly to job satisfaction.

The last hypotheses H8 (There is a positive relationship between education and development of employees and job satisfaction) is fully accepted as the coefficient Beta $(0,267)$ is statistically significant $($ sig. $=0,000)$ and leads us to conclude that educational opportunities and professional training and development of new skills have a positive effect on job satisfaction.

Overall, the most important factor affecting the job satisfaction of employees of the National Bank is the level of salaries, followed by training and development policy.

Table 4: Regression Analysis

\begin{tabular}{|c|c|c|c|c|}
\hline Factors & Coefficients & $\mathbf{t}$ & Sig. & V.I.F \\
\hline Constant & 0,135 & 0,381 & 0,704 & 1,170 \\
\hline Salaries & 0,264 & 4,574 & $0,000^{*}$ & 1,821 \\
\hline $\begin{array}{c}\text { Opportunities for Promotion \& } \\
\text { Evolution }\end{array}$ & 0,126 & 1,938 & $0,054^{* *}$ & 1,997 \\
\hline Empowerment and Participation & 0,138 & 1,779 & $0,077^{* *}$ & 1,034 \\
\hline Organizational Aspects & $-0,014$ & $-0,250$ & 0,803 & 1,936 \\
\hline Relations with supervisors & 0,093 & 1,306 & 0,193 & 1,266 \\
\hline Working Conditions & 0,111 & 1,838 & $0,068^{* *}$ & 1,391 \\
\hline Training and Development & $-0,042$ & $-0,648$ & 0,517 & 1,651 \\
\hline Relations with co- workers & 0,300 & 3,813 & $0,000^{*}$ & 1,170 \\
\hline
\end{tabular}

$*$ at $5 \%$ significance level

** at $10 \%$ significance level 


\section{Conclusion}

From the verification of research hypotheses, it was concluded that the level of remuneration has the most significant impact on overall job satisfaction, which was expected because of the bad conditions of the growing economic crisis, recession and the reductions which were applied to the latest sectoral agreements for bank employees.

This conclusion agrees with the results of Clark and Seward (2000) and Butt et al. (2007) in their research in banking. The education and development policy was found to be the second most important factor that affects job satisfaction, since the National Bank, despite the economic crisis, continues to invest in lifelong learning and its priority is to upgrade the professional knowledge and skills of its staff, through numerous seminars conducted either by the National Bank or from other banking institutions. The crucial importance of education and development in job satisfaction was also mentioned by Kennedy and White (1997) and Butt et al. (2007).

The promotion policy and career development have a significant impact on job satisfaction. The same conclusion was also derived by Sowmya and Panchanatham (2011), in a similar survey in the banking sector in India. However, participants did not appear satisfied with the current promotion procedures. Important steps should be taken to strengthen meritocracy and transparency in these policies and practices in order to create the conditions of impartiality, fairness and reliability in the process of advancement of employees.

A positive effect was also found on job satisfaction by operational factors such as job security, use of skills and abilities and the nature of work. This conclusion agrees with the results of Spector (1997), a survey of the most important factors of job satisfaction. However, the operational factors cause a very small degree of job satisfaction to employees of the National Bank, approaching neutrality. Finally, collegial relationships, which is the factor with the highest participation, was found to have a positive effect on job satisfaction, conclusion that was also derived by both Opkara (2002) and the Lehal (2004). The spirit of teamwork and cooperation, good interpersonal relationships, constructive communication, create the conditions for increased efficiency and constitute a powerful ally in good the good psychology of employees and substantial response in achieving organizational goals.

The findings show that the banking industry should focus its strategy on human resource management practices in order to improve satisfaction of both employees and customers to achieve organizational goals and maximize profits for shareholders banks. At the same time, it can contribute significantly to similar studies examining the impact of other factors on job satisfaction, such as organizational policies and 
strategies, personality of workers, stress at work, the employment strategy and selection etc.

Conducting comparative case studies in other banks in Greece and abroad for job satisfaction, would offer greater generalization and completeness in this investigation. Finally, future researches could be conducted in continues collection of data, comparing them to each other and extracting valuable conclusions.

\section{References}

Abdullah, J. and Djebavni, R. (2011), "Determinants of Job Satisfaction in the UAE. A Case Study of Dubai police", 40 (1), pp. 126-146.

Ahmed, I., Nawaz, M.M., Iqbal, N, Ali, I., Shoukat, Z. and Usman, A. (2010), "Effects of Motivational Factors on Employees Job Satisfaction a case study of University of the Punjab, Pakistan", International Journal of Business and Management, 5 (3).

Akbar, S.W., Yousaf, M., Haq, N.U. and Hunjra, A.I. (2011), "Impact of Employee Empowerment on Job Satisfaction: An Empirical Analysis of Pakistan Service Industry", Interdisciplinary Journal of Contemporary Research In Business, 2(11).

Ali, R. and Ahmed, M.S. (2009), "The Impact Of Rewards And Recognition Programs On Employees Motivation And Satisfaction An Empirical Study", International Review of Business Research Papers, 5 (4), pp. 270-279.

Bernadin, H. J. and Russel E. A. J. (2003), Human Resource Management: An Experimental Approach, McGraw Hill Publishing Co, UK, pp. 19-30.

Butt, B.Z., Rehman, K.U. and Safwan, N. (2007), "A Study Measuring the Effect of Pay, Promotion and Training on Job Satisfaction in Pakistan Service Industry", European Journal of Social Sciences, 5 (3).

Burns, A. C. and Bush, R.F. (1995). Marketing research. Englewood Cliffs, NJ: Prentice-Hall.

Calisir, F., Gumussoy, C.A. and Iskin, I. (2010), "Factors affecting intention to quit among IT professionals in Turkey", Personnel Review, 40 (4), pp. 514-533.

Cambell, A., Converse, P. and Rogers, W. (1976), The Quality of American Life, Russell Sage, New York, NY.

Cao, Q. and Dowlatshahi, S. (2005), "The impact of alignment between virtual enterprise and information technology on business performance in an agile manufacturing environment", Journal of Operations Management, 23, pp. 531-550.

Chow, W.S. and Luk, V. (1996), "Management in the 1990s: A comparative study of women managers in China and Hong Kong", Journal of Managerial Psychology, 11 (1), pp. 2436.

Clark, A.E. (1997), "Job Satisfaction and Gender: Why Women are so happy at Work?", Labour Economics, 4, pp. 341-72.

Clark, R. and Seward, J. (2000), Australian Human Resources Management: Framework \& Practice, McGraw-Hill.

Clercq, D. and Rius, I. (2007), “Organizational Commitment in Mexican Small and MediumSized Firms: The Role of Work Status, Organizational Climate, and Entrepreneurial Orientation", Journal of Small Business Management, 45(4), pp. 467.

Churchill, G.A. (1979), “A paradigm for developing better measures of marketing 
constructs", Journal of Marketing Research, 16, pp. 64-73.

Crowford, R. (1991), "In the era of Human Capital”, Harper Business, New York, pp. 26.

Davis, K. and Newstrom, J. (1999), Comportamiento Humano en el Trabajo: Comportamiento Organizaciona, 10th Edition, McGraw-Hill, Mexico.

Dawson, P. (1987), "Computer Technology and the Job of the First-Line Supervisor New Technology", Work Employment, 2 (1), pp. 47-59.

Elanian, A. (2009), "Job characteristics, work attitudes and behavirors in a non-western context: Distributive Justice as a mediator", Journal of Management Development, 28 (5), pp. 457-477.

Forgionne, G. A. and Peters, V. E. (1982), "Differences in Job Motivation and Satisfaction among Female and Male Managers", Human Relations, 35 (2), pp. 101-118.

Frauenheim, E. (2008), "HR Future View (human resource management in the USA)", Workforce Management, 87 (20) pp.18-23.

Guest, D. E. (2004), "Flexible employment contracts, the psychological contract and employee outcomes: an analysis and review of the evidence", International Journal of Managements Reviews, 5/6 (1), pp. 1-19.

Gratto, F. J. (2001), "The relationship between organizational climate and job satisfaction for directors of physical plants", Unpublished Ph.D., University of Florida, United States Florida.

Grammatikou, K. (2010), "Professional satisfaction of primary school teachers in terms of working conditions", Diploma thesis, Harokopion University, Department of Home Economics and Ecology.

Hair, F., Anderson, R., Tatham, R. and Black, W. (1995), Multivariate Data Analysis with

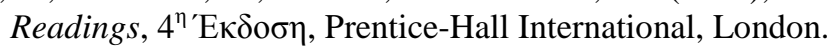

Hanif, M. F. and Kamal, Y. (2009), "Pay and Job Satisfaction: A Comparative Analysis of Different Pakistani Commercial Banks", 9th National Research Conference at SZABIST, Islamabad, Munich Personal RePEc Archive, Islamabad.

Hunjra, AI, Chani, M.I, Aslam, S, Azam, M \& Rehman, K.U. (2010), "Factors effecting job satisfaction of employees in Pakistani banking sector", African Journal of Business Management, 4(10), pp. 2157-2163

Hassan, Y., Kashif, U. D., Mir, Z., Ahmad, K., Mateen, A., Ahmad, W. and Nasir, A. B. (2011), "Job Satisfaction in Private Sector of Pakistan", Global Journal Of Management and Business Research, 11(12).

Hunjra, A.I, Chani, M. I., Aslam, S., Azam, M. and Rehman, K.U. (2010), "Factors effecting job satisfaction of employees in Pakistani banking sector", African Journal of Business Management, 4 (10), pp. 2157-2163.

Iafaldano, M. T. and Muchinsky, P. M. (1985), "Job satisfaction and job performance: A meta-analysis", Psychological Bulletin, 97, pp. 251-273.

Karatepe, O. M., Uladag, O., Menevis, I., Hadzimehmedagic, L. and Baddar, L. (2006), "The Effects of Selected Individual Characteristics on Frontline Employee Performance and Job Satisfaction", Journal of Tourism Management, 27, pp. 547-560.

Kennedy, J. and White, T., (1997), "Service provider training programs at odds with customer requirements in five-star hotels", Journal of Services Marketing, 11 (4), pp. $249-264$.

Lai, H. H.(2011), 'The influence of compensation system design on employee satisfaction", African Journal of Business Management, 5 (26), pp. 1072-1078. 
Lee, E. and Ho, H. (1989), "Quality of work life the case of Hong Kong”, Working Paper Series, Hong Kong Baptist College: Business Research Center, Hong Kong.

Lehal, R. (2004), Research Design in Relation to Study of Organizational Climate, Job Satisfaction and Managerial Effectiveness. Research Methodology in Management Theory and Cases, Deep and Deep Publishers, New Delhi.

Lim, S. (2008), "Job Satisfaction of Information Technology Workers in Academic Libraries", Library and Information Science Research, 30 (2), pp. 115-121.

Mahajan, J., Churchill, G. A., Jr., Ford, N. M. and Walker, O. C., Jr. (1984), “A Comparison of the Impact of Organizational Climate on the Job Satisfaction of Manufacturers' Agents and Company Salespeople: An Exploratory Study" The Journal of Personal Selling \& Sales Management, 4 (1), pp. 1.

Mohanty, S. (2009), "Retention Depicts The Health Of The Organization", Cambodian Management Journal, 1 (2), pp. 1-6.

Nguyen, A. N., Taylor, J. and Bradley, S. (2003), "Relative pay and job satisfaction: some new evidence", 1 (43).

Nunnally, J. C. (1978), Psychometric theory, $2^{\text {nd }}$ edition, McGraw-Hill, New York.

Nicolaidou, A. (2010), "Satisfaction Factors of workers in the Food and Agriculture", Graduate Thesis, Agricultural University of Athens, Department of Agricultural Economics and Development.

Opkara, J. O. (2002), "The impact of salary differential on managerial job satisfaction: A study of the gender gap and its implications for management education and practice in a developing economy", The Journal of Business in Developing Nations, pp. 65-92.

Oshagbemi, T. (2003), "Personal Correlates of Job Satisfaction: Empirical Evidence from UK Universities", International Journal of Social Economics, 30 (12), pp. 1210-1232.

Papageorgiou, M. And Papatzika, L. (2011), "Job satisfaction of teachers of technical education", Annual pedagogical training program ASPAITE, Thessaloniki.

Protopappas, C. (1997), "The challenge of quality and the critical role of the human factor in banks", Press Union of Greek Banks, Issue 12 D.

Pati, G. and Reilly, C. W. (1977), "Reversing discrimination: a perspective. Human Resource Management, 16 (4), pp. 25-31.

Putti, J. M. and Kheun, L. S. (1986), "Organizational Climate-Job Satisfaction Relationship in a Public Sector Organization”. International Journal of Public Administration, 8 (3), pp. 337.

Reed, S. A., Kratchman, S. H. and Strawser, R. H. (1994), "Job Satisfaction, Organizational Commitment and Turnover Intentions of United States Accountants", Accounting, Auditing \& Accountability Journal, 7 (1), pp. 31-58.

Ruth, M. G. (1992), "Organizational Climate and Communication Climate. Predictors of Commitment to the Organization", Management Communication Quarterly: McQ, (1986-1998), 5 (4), pp. 379.

Saleem, S., Majeed, S., Aziz, T. and Usman, M., (2013), "Detetminants of Job Satisfaction among Employees of Banking Industry at Bahawalpur", Journal of Emerging Issues in Economics, Finance and Banking, 1 (2), pp.150-162.

Shaprio, J. and Stern, L. (1975), "Job Satisfaction Male and Female, Professional and NonProfessional Workers", Personnel. Journal, 54, pp. 388-389.

Sharma, S. 1996. Applied Multivariate Techniques. New York, Willey. 
Shrivastava, A. and Purang, P. (2009), "Employee Perceptions of Job Satisfaction: Comparative Study on Indian Banks" Asian Academy of Management Journal, 14 (2), pp.63-78.

Silla, I., Gracia, F. and Peiró, J. M. (2005), "Job insecurity and health-related outcomes among different types of temporary workers, Economic and Industrial. Democracy, 26 (1), pp. 89-117

Sowmya, K. R. and Panchanatham, N. (2011), "Factors influencing job satisfaction of banking sector employees in Chennai, India", Journal of Law and Conflict Resolution, 3 (5), pp.76-79.

Spector, P. (1997), Application, assessment, causes and consequences. CA, Sage Publishers.

Spector, P.E. (1992), Summated Rating Scale Construction: An Introduction, Sage University Paper Series on Quantitative Applications in the Social Sciences. Newbury Park, CA.

Stringer, R, A. (2002), Leadership and Organizational Climate, $1^{\text {st }}$ edition New Jersey, Prentice Hall.

Thakur, M. (2007), "Job Satisfaction in Banking: A Study of Private and Public Sector Banks", The IUP Journal of Bank Management, 6 (4), pp.60-68.

Turkyilmaz, A., Akman, G., Ozkan, C. and Pastuszak, Z. (2011), "Empirical study of public sector employee loyalty and satisfaction", Industrial Management and Data Systems, 111 (5), pp. 675-696.

Vallejo, R. D., Vallejo, J. A. D. and Parra S. O. (2001), "Job Satisfaction in Banking Workers", Psicothema, 13 (4), pp. 629-635.

Ward, M. and Sloane, P. (1998), "Job Satisfaction: The case of the Scottish Academic Profession, Mimeo, University of Aberdeen, Aberdeen.

Weaver, C. N. (1974), "Correlates of Job Satisfaction: Some Evidence from the National Surveys", Academic. Management .Journal, 17 (1), pp. 373-375.

Wilkinson, A. (1998), "Empowerment: theory and practice", Personnel Review, 27 (1), pp. $40-56$.

Wixom, B.H. and Watson, H.J. (2001), “An empirical investigation of the factors affecting data warehousing", MIS Quarterly, 25(1), 17-41.

Zikmund, W. G. (2003), Business Research Methods, Thomson Southwestern, Ohio. 